\title{
III. AWARDS OF THE PRESIDIUM OF THE NATIONAL ACADEMNY OF SCIENCES OF UKRAINE TO SCIENTISTS OF THE S. P. TIMOSHENKO INSTITUTE OF MECHANICS
}

\section{D. Kubenko}

The General Meetings OF NASU of December 7, 2018 devoted to the 100th Anniversary of the National Academy of Sciences of Ukraine, the General Meetings of the Mechanics Division of December 21, 2018 devoted to the 100th Anniversiry of the S. P. Timoshenko Institute of Mechanics, and the meeting of the Academic Council of the S. P. Timoshenko Institute of Mechanics of December 26, 2018 devoted to the 100th Anniversary of the S. P. Timoshenko Institute of Mechanics, awarded scientists of the S. P. Timoshenko Institute of Mechanics, the prizes of the NASU Presidium.

Anniversary Honorary Certificates of the NASU Presidium were awarded to:

1. Academic Secretary of the Institute, Doctor of Physical and Mathematical Sciences

Oleksandr Petrovych Zhuk.

2. Head of the Department of Thermoplasticity, Doctor of Technical Sciences

Oleksandr Zakirianovych Halishyn.

3. Head of the Department of Creep Mechanics, Doctor of Technical Sciences

Vladyslav Petrovych Holub.

4. Head of the Department of Numerical Methods, Doctor of Physical-Mathematical Sciences

Oleksandr Yaroslavovych Hryhorenko.

5. Head of the Department of Mechanics of Material Destruction, Doctor of Physical and Mathematical Sciences Anatoliy Oleksiyovych Kaminskyiv.

6. Head of the Department of Thermoelasticity, Doctor of Physical and Mathematical Sciences

Vasyl Havrylovych Karnaukhov.

7. Head Department of Structural Mechanics of Thin-walled structures, Doctor of Technical Sciences

Petro Zakharovych Luhovyi.

8. General Deputy Director of the Institute

Oleksandr Mykhailovych Sytnik.

Award of the NAS of Ukraine "For Scientific Achievements" were granted to:

1. Headof the Department of Creep Theory, Doctor of Technical Sciences

Vladyslav Petrovych Holub.

2. Head of the Department of Fracture Mechanics, Doctor of Physical and Mathematical Sciences

Anatoliy Oleksiyovych Kaminskyi

3. Head of the Department of Thermoelasticity, Doctor of Physical and Mathematical Sciences

Vasyl Havrylovych Karnaukhov.

4. Leading Researcher, Doctor of Physical and Mathematical Sciences

Volodymyr Borysovych Larin.

5. Head of the Department of Structural Mechanics and Thin-Walled Structures, Doctor of Technical Sciences

Petro Zakharovych Luhovyi. 
Award of NAS of Ukraine "For Training Young Scientists" were granted to:

1. Director of the Institute, NASU Academician,

Oleksandr Mykolayovych Guz.

2. Head of the Department of Numerical Methods, Doctor of Physical and Mathematical Sciences

Oleksandr Yaroslavovych Hryhorenko.

Award of NASU "For Professional Achievements" were granted to:

1. Leading Researcher, Doctor of Physical and Mathematical Sciences

Olena Ivanivna Bespalova.

2. Head of the Department of Thermoplasticity, Doctor of Technical Sciences

Oleksandr Zakirianovych Halishyn.

3. Leading Researcher, Doctor of Physical and Mathematical Sciences

Borys Mykytovych Kiforenko.

4. Leading Researcher, Doctor of Physical and Mathematical Sciences

Volodymyr Fedorovych Meish.

"Memorable Award to the 100th Anniversary of NAS Ukraine" of the Board of NAS of Ukraine were granted to:

1. Director of the Institute, NASU Academician,

Oleksandr Mykolayovych Guz.

2. Principal Researcher, NASU Academician

Yaroslav Mykhailovych Grygorenko.

3. Research Deputy Director of the Institute, NASU Academician

Veniamin Dmytrovych Kubenko.

4. Head of the Department of Process Stability, NASU Academician

Anatoliy Andriyovych Martyniuk.

5. Head of the Department of Numerical Mechanics and Engineering,

NASU Corresponding Member

Volodymyr Mykhailovych Nazarenko.

6. Head of the Department of Rheology, NASU Corresponding Member

Yarema Yaroslavovych Rushchytskyi.

7. Head of the Department of the Mechanics of Stochastic Inhomogenous Media, NASU Corresponding Member

Leonid Petrovych Khoroshun.

8. Principal Researcher, NASU Corresponding Member

Ivan Semenovych Chernyshenko.

9. Principal Accountant of the Institute

Nadia Mykolaivna Bek.

10. Researcher, Candidate of Physical and Mathematical Sciences

Olena Oleksandrivna Khotenko.

Honorary Certificate of the Board of NASU and Central Committe of the Trade Union of the NASU was granted to: Senior Researcher, Candidate of Physical and Mathematical Sciences

Neonila Yermolaivna Tkachenko.

Gratitude Certificate of the NASU Board was granted to

Head of the Scientific and Technical Library of the Institute

Olena Alimivna Myronenko.

Deputy Director of the S.P. Timoshenko Institute of Mechanics

of the NASU 